\title{
The Development of Learning Device to Improve the Quality and Learning Result of Mathematics
}

\author{
Atma Murni, Rini Dian Anggraini \\ Departement of Mathematics \\ Universitas Riau \\ Riau, Indonesia \\ atma.murni@unri.ac.id
}

\begin{abstract}
The aims of this development research were: (1) to produce a learning device in the form of Lesson Plan (LP) and Student Activities Sheet (SAS) at Relation and Function as main subjects which were appropriate to be used in Mathematics learning of class VIII, (2) to describe the appropriateness of the learning device that has been produced, and (3) to describe the quality of learning and learning result after using the learning device that has been arranged. The limited trial involved 16 students and the field trial involved 24 students. The instruments of data collection were observation sheets, interview guides, and test of learning result. The data were analyzed using qualitative descriptive and descriptive statistical analysis. The results of this study were: (1) the learning device has been obtained through seven of ten stages of development from Borg \& Gall; (2) the learning device is appropriate to use in class VIII; and (3) the learning device can improve the quality of learning and students' learning result at relation and function subject.
\end{abstract}

Keywords- Development; Learning Device; Quality

\section{INTRODUCTION}

The 2013 curriculum for junior high school students in Pekanbaru was applied in academic year 2013/2014 in six schools which consisted of three public schools and three private schools. The implementation was supported by some roles from Ministry of Education and Culture, which were related to competency standards, content standards, process standards, assessment standards, textbook, and teacher's guidebook. Furthermore, syllabus is also applied nationally. With the syllabus and textbook that have been provided in the national level, teachers are demanded to prepare and implement the learning accurately. The textbook spells out the students' minimum effort to achieve the competence expected. The role of the teacher is very important to increase and adjust the students' ability with the availability of activities on the students' book [1].

Teachers can develop the students' ability in the form of the other appropriate and relevant activities which come from the social and natural environment. Therefore, teachers must be able to design a learning device that is appropriate with the basic competencies to be achieved and challenges the process of the students' thinking through the activities to reach the attitude, knowledge and skills [2].
Therefore, schools in Pekanbaru do some ways in implementing the learning. There is a teacher implementing the learning by assigning the students to discuss the problems in the textbook individually and groups. Moreover, there is a teacher using another problem to be discussed by the students but the problem is not provided yet in the form of student activities sheet which challenges the students to think and involve actively in learning.

The information obtained from the teachers of SMP that have applied the 2013 curriculum is as follows: (1) teachers feel overwhelmed in designing lesson plan for each meeting accurately which is appropriate with the curriculum and (2) teachers cannot create student activities sheet which challenge the students to involve actively in constructing their knowledge. Basically, schools have already had learning device such as lesson plan and student activities sheet, but learning device that is designed by the teachers does not yet describe the students' participation actively in learning. Learning device used by the teachers is not yet arranged based on the understanding on each learning component. Therefore, teachers are not ready in developing a learning device individually which is appropriate with the 2013 curriculum. According to [3], in designing a good learning device, a teacher must understand the purposes of the learning that should be achieved by the students, learning materials which are going to be learned, methods, learning techniques and the ways to design the assessment tool.

The application of the 2013 curriculum requires learning media which can make students reach the competence of attitude, skill, and knowledge that has been formulated at graduate competence standard (SKL). As stated in the role from Ministry Education and Culture No. 22 year 2016 that learning process in educational units is organized interactively, in inspiring form, fun, challenging, motivating students to participate actively, as well as providing enough room for initiative, creativity, and self-sufficiency in accordance with talents, interests, physical, and psychological development of students.

Based on the difficulty experienced by teachers in implementing the 2013 curriculum, it is necessary to do a development research related to learning media consisting of lesson plan and student activities sheet in mathematics. Lesson 
plan can be utilized by teachers as guide in implementing the learning and student activities sheet as one of learning sources for students so that it can enhance quality of process and students' learning achievement. This study is expected to generate learning device which can develop activity, creativity, and productivity of students in learning mathematics. This paper presents the report of the implementation of the development research related to Relations and Functions material in class VIII through the application of cooperative learning approach Think Pair Square (TPS).

Think Pair Square (TPS) is one of approaches that gives opportunity to students to work alone and work together with other students [4]. At first, students are given opportunity to build their own knowledge and think actively in discovering concept of material that is learned (think) so that they can develop their ability in mastering the material. This is in accordance with the learning theory of Constructivism which states that students must find their own knowledge, really understand it and can apply their knowledge. Next, students discuss to solve problems with their pair in one group (pair). Students will exchange opinions on the knowledge that has been acquired at an earlier stage. Students have the opportunity to discuss with students who have high academic ability or with students who have medium and low academic ability. Thus, students can see the other way in solving problem. In this stage, students can develop their knowledge, test the ideas and their own understanding. In the end, students can unify ideas between pair in one group (square). In this stage, students will become easier to reconstruct their knowledge.

\section{METHOD}

This research and development was done by using seven of ten stages of development from Borg \& Gall [5]. The activities undertaken at each stage of development are as follows.

(1) Research and information collecting: (a) Analysis of curriculum to analyze Standard Competency 3.3 and Standard Competency 4.3 mathematics subjects for grade VIII in Indonesian curriculum; (b) Analysis of learning devices made by teacher and compare with the provisions set by the 2013 curriculum; (c). Analysis of student characteristics related to the initial knowledge and level of thinking; (d) Analysis of learning materials by identifying, detailing, and systematically compiling relevant concepts.

(2). Planning. In this stage, lesson plan and student activities sheet were designed based on needs analysis. Lesson plan and student activities sheet are prepared for six meetings, covering learning materials: (a) to understand relation and how to express it; (b) to understand function and how to express it; (c) determine the number of mappings in two sets and one-to-one correspondence; (d) the function formula, function value, and value of the change; (e) express a function form if the value and function are known; (f) application of relation and function in daily life.

(3). Developing preliminary form of product: (a) discussing the design of lesson plan and student activities sheet with three mathematics teacher; (b) validating the design of lesson plan and student activities sheet by validator that are three lecturer of Mathematics Education. The validators assesed the design of lesson plan and student activities sheet by filling the validation sheet. The design of lesson plan and student activities sheet were revised according to validator's suggestion.

(4) Preliminary field testing. The lesson plan and student activities sheet were tested on a small scale (limited trial) involving 16 students grade VIII Babusalam Junior High School. The students were asked to do student activities sheet and fill a student response questionnaire about student activities sheet and completed with interview.

(5) Main product revision. The trial results are used to fix design of lesson plan and student activities sheet so that produce a product called prototype I.

(6) Main field testing. The prototype I was tested on the real subjects of 24 students from grade VIII of Babussalam Junior High School. The teacher was asked to implement learning based on lesson plan that has been arranged. Students are required to learn by using student activities sheet.

(7). Operational product revision. The trial results are used to improve prototype I so that a product called prototype II was produced. Stages 8 to 10 have not been done in this research, which were: operational field testing; final product revision; and dissemination and implementation.

The data of this research were qualitative and quantitative. Qualitative data owere btained from: comments and suggestions from validator on lesson plan and student activities sheet; and observation result of the implementation of lesson plan. Qualitative data were also obtained from discussions with students and teachers. Quantitative data were obtained from questionnaires given to validators to assess lesson plan, student activities sheet and student response questionnaire on student activities sheet.

Validation sheet of lesson plan and student activities sheet using Likert scale consisted of four alternative answers, namely 1, 2, 3, and 4 which were catgeorized as very unsuitable, inappropriate, appropriate, and highly appropriate. The validation sheet of lesson plan was created to assess the aspects of subject identity, indicators and instructional goal, materials selection, learning method selection, learning activity with cooperative learning of TPS, learning source selection, and assessment of learning outcome. The validation sheet of student activities sheet was created to assess the quality of student activities sheet materials content, suitability of student activities sheet with cooperative learning of TPS, suitability of student activities sheet with didactic conditions, suitability of student activities sheet with construction requirements, and suitability of student activities sheet with technical requirements. Student response questionnaire on student activities sheet used Guttman scale consisting of two alternative answers, namely Yes or No. The questionnaire contained some statements consisting of positive and negative statements and viewed from the following aspects: language, display, picture, and content of student activities sheet.

The validation sheet of lesson plan and student activities sheet were analysed using the following mean formula [6]. 


$$
\bar{M}_{v}=\frac{\sum_{i=1}^{n} \bar{V}_{i}}{n}
$$

Where $=$ average total validation; $\bar{V}_{i} \quad=$ average validation of the $\mathrm{i}$-validator and $n:$ number of validators The category of validity using criteria from [7] and can be seen in Table 1.

TABLE I. VALIDITY CATEGORY OF LEARNING DEVICE

\begin{tabular}{|c|c|}
\hline Interval & Category \\
\hline $3,25 \leq \bar{x}<4$ & Highly Valid \\
\hline $2,50 \leq \bar{x}<3,25$ & Valid \\
\hline $1,75 \leq \bar{x}<2,50$ & Fairly Valid \\
\hline $1,00 \leq \bar{x}<1,75$ & Invalid \\
\hline
\end{tabular}

Students' responses on student activities sheet were analysed using Q Cochran test. Moreover, open observation was used to observe the implementation of lesson plan. The observer was the teacher.

\section{RESULTS AND DISCUSSION}

The purpose of this Research and Development was to produce lesson plan and student activities sheet at the topics of Relation and Function in the eighth class. The development was started from the phase of potential and the problems from need analyses that the researcher did, involving: content and base competences, students' characteristic, and material analysis. Then, the material needed for designing learning device was collected. The learning device which has been arranged was validated. The average validation score of lesson plan was 3.79 and student activities sheet was 3.82. As a whole, learning device was viewed as very valid. The validators stated that the learning device was suitable to be tried out with revision based on the advices given. Validated lesson plan and student activities sheet were analyzed and used as the base to revise design.

The validated learning device was tried out in small group, and students' responses were asked through Student activities sheet. The result of Q Cochran test showed that the students' response was good. Then, the researchers revised the learning device based on the result of trying out to small group. The result was prototype I.

After that, the researchers tried out it in the large group in the classroom at the school regular time. In this phase, the teacher was asked to handle teaching suitable with the lesson plan has been arranged and the students learn how to use student activities sheet that has been developed. The field try out was done in class VIII4 of SMP Babussalam. The material was Relation and Function. The teaching process was done twice a week, three hour period and two hour period.

At the Think phase, students' activities were increased at every meeting. At the first meeting, the students have not got self-confidence to do student activities sheet individually. As a result, the students were lazy to read student activities sheet. Some students discussed with friends and copied other students' answers. However, the researchers always reminded students to do student activities sheet individually and there would be the time for discussing. For the next meeting, the students became more familiar to the phase of Think Pair Square, and the researchers only administered the process of learning.

At the first pair phase, there were still many pairs of students who did not discuss. Some have not seriously discussed in pairs. The students just copied others' work. There were some students who directly discussed with the group. These faults were decreased in the next meeting.

At Square phase in the first meeting, the students have not done discussion well. Some students have not taken part in the activities of group discussion. It was signed by the students who were joking and chatting each other. There were some members of the group working individually and also those who did not participate in the group discussion. The researchers gave explanation in order to have awareness to participate in the discussion activities, and also do good tasks arrangement of group member in writing the result of discussion. At the next meeting, the students started to be active in discussion activities. In this phase, the researchers gave guidance to the group which found difficulties in doing student activities sheet. Students' activities in discussion activities were increased at every meeting.

Students' presentation has been done well. The students became more active and thought critically in giving response and opinion to the group of presenter. Moreover, the students looked active to share the conclusion of material learned. Students' activities have been done well and suitable to the planning. The researchers also have organized the time well. Thus all teachers and students activities run well as the planning.

The result of Q Cochran test of trying out in large group showed that the students' response toward Mathematics lesson set was good. The researchers revised the lesson set to be suitable to the result of large group try out, and it became prototype II.

Based on the result of observation toward teacher and students' activities, it can be stated that by applying cooperative learning, TPS approach increased at every meeting. The students participated actively in learning process through stated phases of learning. The students were asked to optimize responsibility in the phase of individual thinking and group discussion to understand given material. According to [8], cooperative learning model is suitable to make sure individual accountability in group discussion that guarantee involving all students and become excellent effort to increase individual responsibility in group discussion.

Applying learning model with TPS approach in this learning has given a chance to students to comprehend lesson material and increase students' participation in group discussion. TPS is a technique that provides the students opportunity to work individually and cooperate with others [4]. 
Another superiority of this technique is how to optimize students' participation.

Percentage of the students who reached Minimum Mastery Criteria (MMC) increased from 23.07 to 61.53 . The increasing of students' percentage showed that there was the increasing of students' achievement. The increasing of students' achievement occurred because in cooperative learning with TPS approach, the students with groups were given opportunity to actively participate in order to discover the concept of material individually. By discovering, learning becomes meaningful, and the knowledge is stored in long term memory. Constructivism theory from [8] mentions that learning will be more meaningful for students if they construct the concept by their own than only accept the teacher's explanation.

\section{CONCLUSION}

This research and development has produced products in form of Lesson Plan and Student Activities Sheet at Relation and Function as main subject through the application of cooperative learning of Think Pair Square for six meetings. The learning device is considered valid after validation process by validator and practical to use by learners for grade VIII after a limited trial and large group trial. The resulting product can improve the quality of learning and students' learning result.

\section{REFERENCES}

[1] Kemendikbud, Permendikbud No.22 Tahun 2016 tentang Standar Proses, Jakarta: Kemendikbud, 2016.

[2] J. Sabandar, "Thinking Classroom dalam Pembelajaran Matematika di Sekolah," in Teori, Paradigma, Prinsip dan Pendekatan Pembelajaran MIPA dalam Konteks Indonesia, Bandung, FMIPA UPI, 2010.

[3] N. Sudjana, Dasar Proses Belajar Mengajar, Bandung: Sinar BAru Algensindo, 2002.

[4] A. Lie, Cooperative Learning, Jakarta: Grasindo, 2008.

[5] W. R. Borg and M. D. Gall, Eduactional Research, Boston: Pearson Education, Inc, 2003.

[6] A. Sudjiono, Pengantar Statistik Pendidikan, Jakarta: Rajawali Press, 2011.

[7] S. Arikunto, Evaluasi Program Pendidikan, Jakarta: Bumi Aksara, 2004.

[8] R. E. Slavin, Cooperative Learning, Teori, Riset, dan Praktik, Bandung: Nusa Media, 2010. 